\title{
Simultaneous Quantitation of Several mRNA Species by Calibrated Reverse Transcription Polymerase Chain Reaction and Capillary Electrophoresis: Analysis of the Epidermal Growth Factor Receptor and its Activating Ligands EGF, TGF- $\alpha$, and HB-EGF in Rat Liver
}

\author{
Mustafa Vakur Bor, Boe Sandahl Sørensen, and Ebba Nexø \\ Department of Clinical Biochemistry, AKH Aarhus University Hospital, Denmark
}

$T$ he amount of a specific mRNA can be determined by reverse transcription polymerase chain reaction (RT-PCR) coamplification of sample RNA with several dilutions of an internal standard, which requires four or five reactions per RNA sample (Siebert and Larrick, 1992). Recently, we (Bor et al, 1998) and others (Tsai and Wiltbank, 1996; Vats et al, 1997) have modified this assay design by using a calibration curve and only one RT-PCR reaction for each sample. In this paper, we extend this methodology to a multiplex format combined with the increased sensitivity of capillary electrophoresis (CE). This allows us to quantitate several mRNA species simultaneously in minute amounts of sample. Using the expression of the epidermal growth factor (EGF) system in rat liver as a model, we have developed a method that quantifies mRNA for the EGF receptor (EGFR) and its activating ligands, EGF, transforming growth factor alpha (TGF- $\alpha$ ), and heparin binding EGF-like growth factor (HB-EGF). The method is based on the generation of specific RNA standards for each of the target sequences (Table 1). The four standards are RT-PCR-amplified in the same test tube with mRNA from either the unknown sample or one of the seven calibrators. Quantitative analysis of the obtained RT-PCR products was performed using an automated system that combines CE for high-efficiency separation and laser induced fluorescence for high-sensitivity de-

Received January 21, 2000.

The presented work was supported by the Danish Medical Research Council (95-03044 and 97-00592).

Address reprint requests to: Dr. M. Vakur Bor, Department of Clinical Biochemistry, AKH, University Hospital of Aarhus, Norrebrogade 44, DK-8000 Aarhus C, Denmark. Fax: 4589493 060; E mail: vakbor@hotmail.com tection (Lu et al, 1994) (Fig. 1). Linear calibration curves were obtained, and the amount of mRNA for each component in the unknown samples was calculated from the calibration curve based on the ratio between the target mRNA and the corresponding RNA standard (Fig. 2). Our approach allows quantitation of several mRNA species simultaneously over a range of approximately 125-fold difference between the highest and lowest calibrator and a 100-fold difference between the highest and lowest absolute concentrations of mRNA for the individual components (eg, EGFR versus HB-EGF). Further, due to the selection of the primers (Table 1), the method can be used for quantitation of mRNA in several different species. The precision was calculated from analyses of the same preparation of rat liver RNA (400 ng or $50 \mathrm{ng}$ total RNA) at eight occasions. Comparable results were obtained independent of the amount of total RNA used, however the imprecision increased when low amounts of total RNA was used. The results for precision and mean values $\left(10^{-18} \mathrm{~mol}\right.$ specific $\mathrm{mRNA} / \mu \mathrm{g}$ total RNA) of the 400 ng RNA sample (with the 50 ng RNA sample in parenthesis) were: EGF, 10\% (17\%) with mean values of 1.3 (1.1); EGFR, 9\% (24\%) with mean values of 32.9 (32.5); TGF- $\alpha, 11 \%$ (23\%) with mean values of 11.2 (12.7); and HB-EGF, $12 \%$ (19\%) with mean values of 0.30 (0.43). Thus, as little as 50 ng total RNA corresponding to approximately $10 \mu \mathrm{g}$ liver sample is sufficient for quantitation of all four mRNA species with a precision of approximately $20 \%$. This makes the method suitable for clinical applications, in which the material often is present in low amounts.

Total cellular RNA was isolated from homogenized rat liver with the Purescript kit (Gentra, Min- 
Table 1. Primers Used for Quantitation of EGFR, TGF- $\alpha$, EGF, and HB-EGF

\begin{tabular}{|c|c|c|c|c|c|c|}
\hline & $\begin{array}{l}\text { Gene specific primers Sense primer } \\
\text { (SP)/Anti-sense primer (AP) }\end{array}$ & $\begin{array}{l}\text { Labeling } \\
\text { dye }\end{array}$ & $\begin{array}{l}\text { Target } \\
\text { size }\end{array}$ & $\begin{array}{l}\text { Standard } \\
\text { size }\end{array}$ & $\begin{array}{l}\text { Primer } \\
\text { amount }^{a}\end{array}$ & Species \\
\hline EGFR & $\begin{array}{l}\text { SP 5'-GAGAGGAGAACTGCCAGAA-3' } \\
\text { AP 5'-GTAGCATTTATGGAGAGTG-3' }\end{array}$ & TET & 454bp & 314bp & $4 \mathrm{pmol}$ & Rat, mouse, human \\
\hline EGF & $\begin{array}{l}\text { SP 5'-AGCAATTGGTGGTGGATG-3' } \\
\text { AP 5'-ACTCTTTGCAAAAGTTGTC-3' }\end{array}$ & HEX & $103 b p$ & $163 b p$ & 10pmol & Rat, human \\
\hline TGF- $\alpha$ & $\begin{array}{l}\text { SP 5'-GCTGCAGCGCCTGCGCTCGGAAG-3' } \\
\text { AP 5'-CATCGGCCACCTGGCCAAATTCCT-3' }\end{array}$ & TET & $540 b p$ & $604 b p$ & 30pmol & Rat, mouse ${ }^{b}$ \\
\hline HB-EGF & $\begin{array}{l}\text { SP 5'-GTGCCTAGACTGTTACTTTG-3' } \\
\text { AP 5'-GAAATGTAGACAGACAATAAAT-3' }\end{array}$ & TET & $126 b p$ & $168 \mathrm{bp}$ & 20pmol & Rat, human, mouse \\
\hline
\end{tabular}

TET: 4, 7, 2' , 7'-Tetrachloro-6-carboxyfluorescein; HEX: 4, 7, 2' , 4', 5' , 7'-Hexachloro-6-carboxyfluorescein; bp: base pair.

${ }^{a}$ Total amounts of primers in the PCR reaction.

${ }^{b}$ Mismatches at the underlined positions are present in the mouse TGF-101.

neapolis, Minnesota) according to the instructions provided by the manufacturer, except that an extra centrifugation $\left(16,000 \times \mathrm{g}, 6 \mathrm{~min}, 4^{\circ} \mathrm{C}\right)$ was included in the protein-DNA precipitation step. The concentration and purity of the RNA preparations were analyzed by optical density at wavelengths of 260 and $280 \mathrm{~nm}$ (GeneQuant II, Pharmacia Biotech, Uppsala, Sweden). Four RNA standards were constructed with different sizes for each of the target sequences by using the PCR MIMIC construction kit (Clontech, Palo Alto, California) as previously described for the EGFR (Bor et al, 1998). Equal efficiency of the RT-PCR amplification of target mRNA and corresponding RNA standard was confirmed (as described in Bor et al, 1998) by demonstrating that the ratio of RT-PCR products derived from sample and standard remained constant irrespective of the number of PCR cycles investigated (data not shown). Constant amounts of RNA standards ([all expressed as $10^{-18} \mathrm{~mol}$ RNA) EGFR, 3.6; EGF, 0.7; TGF- $\alpha, 5$; HB-EGF, 0.08] were added into a reverse transcription master mixture containing $50 \mathrm{~mm} \mathrm{KCl}$, $10 \mathrm{~mm}$ Tris- $\mathrm{HCl}$ ( $\mathrm{pH} 8.3), 6.25 \mathrm{~mm} \mathrm{MgCl}, 1$ unit/ $\mu \mathrm{l}$ RN'ase inhibitor, $1 \mathrm{~mm}$ deoxyribonucleosid triphosphates (dATP, dCTP, dTTP, dGTP), $2.5 \mu \mathrm{M}$ of a 16 mer $d(T)_{16}$ oligonucleotide primer, and 2.5 units $/ \mu$ l reverse transcriptase (all reaction components were from Perkin Elmer, Foster City, California). This master mix was then aliquoted into $0.2 \mathrm{ml}$ PCR tubes, which ensured that the same amount of the RNA standards was present in each aliquot. Thereafter known amounts of two-fold serial dilutions of calibrators or unknown samples were added to each tube. The calibrator was prepared from a pool of liver RNA, and the amounts of EGFR, EGF, TGF- $\alpha$, and HB-EGF present in the stock solution of the calibrator were $\left(10^{-18} \mathrm{~mol}\right.$ specific $\mathrm{mRNA} / \mu \mathrm{g}$ total RNA) EGFR, 37; EGF, 1.3; TGF- $\alpha, 13$; and HB-EGF, 0.325 (mean values, $n=4$ ) as determined by conventional competitive RT-PCR with dilutions of RNA standards as previously described for the EGFR (Bor et al, 1998). Reverse transcription was performed at $42^{\circ} \mathrm{C}$ for 30 minutes followed by heating to $99^{\circ} \mathrm{C}$ for 5 minutes. Reverse transcription product $(2.5 \mu \mathrm{l})$ was mixed with $22.5 \mu \mathrm{l}$ of PCR buffer containing $50 \mathrm{~mm} \mathrm{KCl}, 10 \mathrm{~mm}$ Tris- $\mathrm{HCl}(\mathrm{pH}$ 9.0), $1.5 \mathrm{~mm} \mathrm{MgCl}_{2}, 0.2 \mathrm{~mm}$ deoxyribonucleosid triphosphates (dATP, dCTP, dTTP, dGTP), 1.25 units of Taq DNA polymerase (Pharmacia), and gene specific primers. One primer of each primer pair was labeled with a fluorescent tag attached to the $5^{\prime}$-end (Table 1). All reactions were initially denatured at $94^{\circ} \mathrm{C}$ for 1 minute before PCR amplification. Standard cycling program was as follows: $94^{\circ} \mathrm{C}$ for 1 minute; $57^{\circ} \mathrm{C}$ for 30 seconds; $72^{\circ} \mathrm{C}$ for 60 seconds. After 30 cycles the PCR products were extended at $72^{\circ} \mathrm{C}$ for 7 minutes. Quantitation of mRNA for EGFR, TGF- $\alpha$, EGF (Bor et al, 2000), and HB-EGF was first developed for each mRNA species individually. The annealing temperatures used in the individual assays were: EGF, $54^{\circ} \mathrm{C}$; EGFR, $57^{\circ} \mathrm{C}$; HB$\mathrm{EGF}, 59^{\circ} \mathrm{C}$; and TGF- $\alpha, 65^{\circ} \mathrm{C}$. An intermediate annealing temperature $\left(57^{\circ} \mathrm{C}\right)$ was found to be suitable in the multiplex assay. Primer concentrations used in the multiplex assay were adjusted to generate RT-PCR products of measurable intensity at this common annealing temperature. Comparable results were obtained when the same samples used in the present study were analyzed by individual RT-PCR assays by a previously published method (Bor et al, 2000) (data not shown). The ABI 310 Genetic analyzer (Perkin Elmer ABI) was used for CE. Samples were prepared by mixing $1 \mu \mathrm{l}$ PCR product with $12 \mu \mathrm{l}$ formamide and $1 \mu \mathrm{l}$ size marker (Tamra-500). The samples were denatured for 3 minutes at $95^{\circ} \mathrm{C}$, snap-cooled before analysis, and injected at $15 \mathrm{kV}$ for 5 seconds into a $47 \mathrm{~cm} \times 50$ $\mu \mathrm{m}$ capillary containing POP-4 polymer (Perkin Elmer ABI). Electrophoresis was performed at $15 \mathrm{kV}$ for 35 minutes at $60^{\circ} \mathrm{C}$. Gene Scan Analyzer Buffer containing EDTA was used as running buffer. All fluorescent dyes were detected by filter set C. Internal size standard labeled with Tamra dye was run together with the dye labeled unknown fragments in the same capillary under the same electrophoretic conditions. This makes it possible to determine accurate molecular length and overcome the variations according to differences in electrophoretic conditions (Fig. 1). Data represented as 

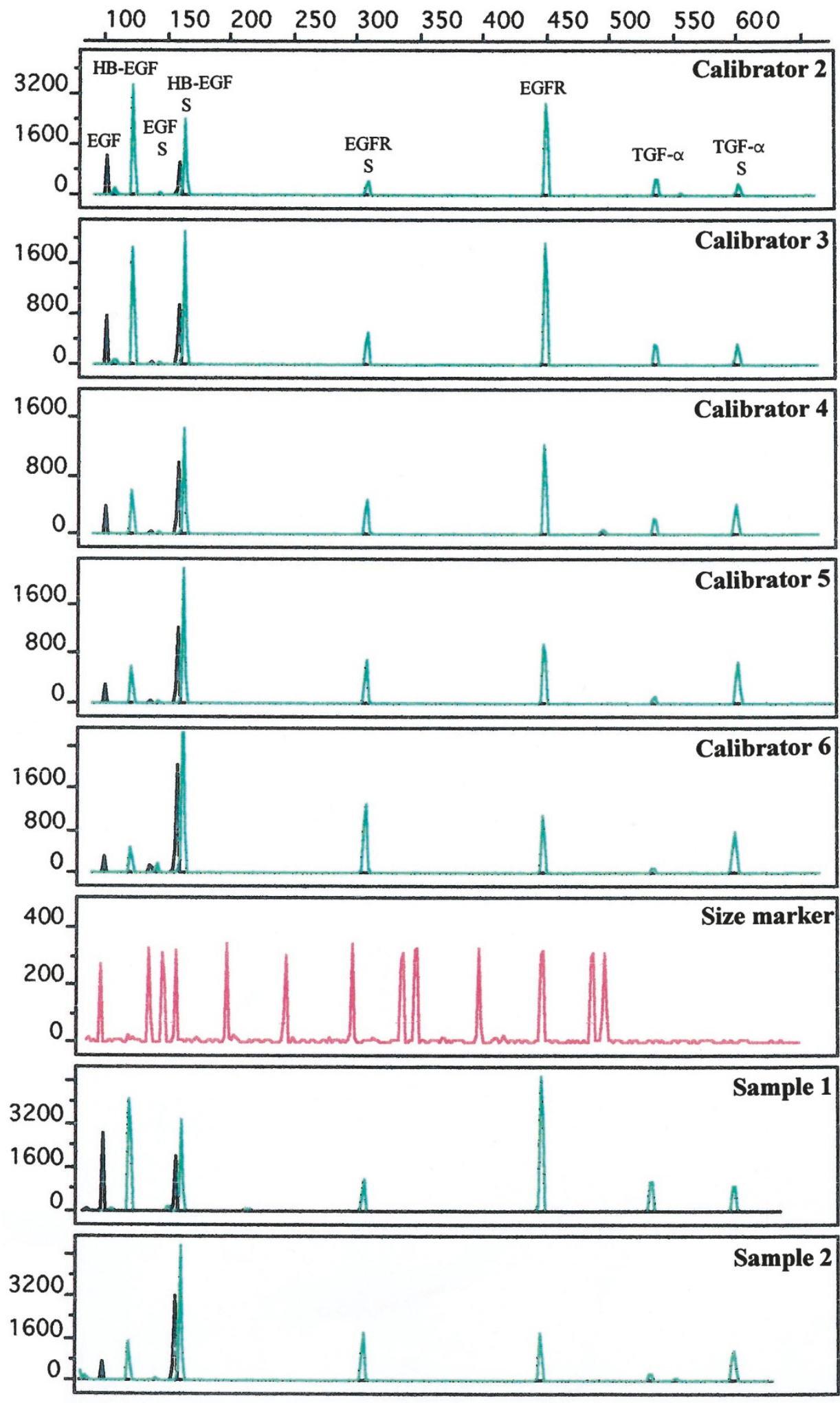

\section{Figure 1.}

Electropherograms of five calibrators containing 410, 205, 102.5, 51.3, and $25.7 \mathrm{ng}$ RNA and two liver samples containing 400 and $50 \mathrm{ng}$ RNA. Calibrators and samples were RT-PCR amplified with fixed amounts of RNA standards. The PCR products originating from the specific mRNA target and the corresponding standard (S) for HB-EGF (target: 126, standard: 168 bp), EGFR (target: 454, standard: 314 bp), and TGF- $\alpha$ (target: 540, standard: 604 bp) were labeled with TET dye (green peaks), while EGF (target: 103, standard: 163 bp) was labeled with HEX dye (black peaks). Gene Scan-500 standard labeled with Tamra (red peaks) was used as a size marker. The molecular mass is displayed at the horizontal axis at the top of the electropherograms, and the fluorescent intensity is displayed along the vertical axis. Different fluorescent intensity ranges were used in the presented electropherograms. The ratio between the signal obtained for the specific mRNA and the corresponding standard decreases from calibrator 2 to calibrator 6 . Electropherograms of calibrator 1 and 7 containing 820 and 12.9 ng RNA were not included due to limitations of space. 
A
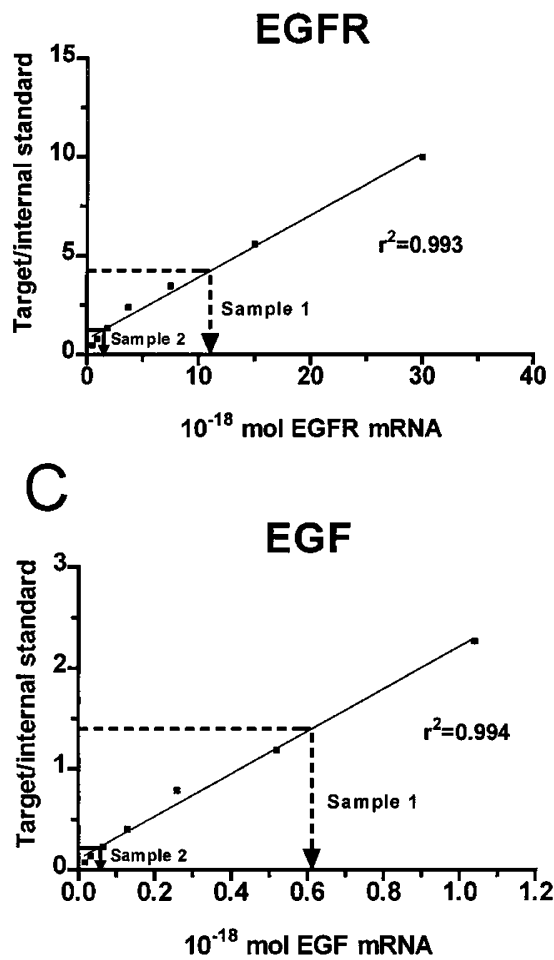

B
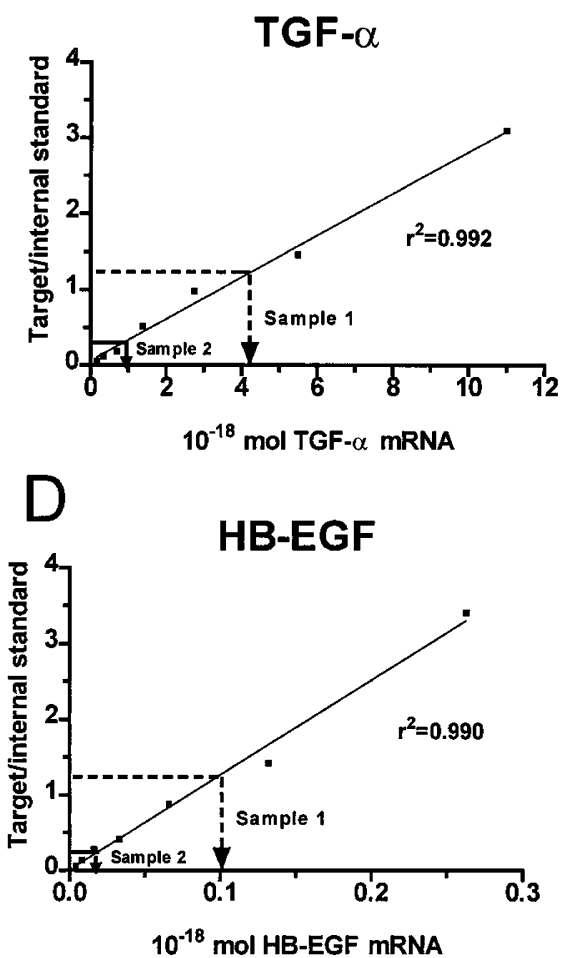

Figure 2.

Calibration curves for EGFR (A), TGF- $\alpha(B)$, EGF (C), and HB-EGF (D). Calibration curves were developed by plotting the ratio between calibrator and RNA standard signal (data obtained from electropherograms as illustrated in Figure 1) against the amounts of EGF, TGF- $\alpha$, HB-EGF, or EGFR mRNA present in the calibrator. Linear calibration curves covering the following ranges: EGF, 0.016-1.04; TGF- $\alpha, 0.17-11$; HB-EGF, $0.004-0.26$; and EGFR, 0.49-30 (all in 10-18 mol specific mRNA) were obtained. The amount of EGFR, EGF, TGF- $\alpha$, and HB-EGF present in the liver samples containing 400 ng RNA (Sample 1) or 50 ng RNA (Sample 2) were determined from the calibration curves based on the ratio between the target mRNA and the corresponding RNA standard (data obtained from electropherograms as illustrated in Fig. 1). The results obtained for Sample 1 (Sample 2 in parenthesis) were (expressed as $10^{-18} \mathrm{~mol}$ specific mRNA/ $\mu \mathrm{g}$ total RNA): EGFR, 28 (24); TGF- $\alpha, 11$ (16); EGF, 1.6 (1.2); and HB-EGF, 0.3 (0.4). Arrows indicates the amount of specific mRNA in 400 ng RNA (Sample 1) or 50 ng RNA (Sample 2).

peak heights were analyzed in the $\mathrm{ABI}$ Genescan analysis software (Perkin Elmer ABI).

In conclusion, we present a method that allows simultaneous quantification of the absolute amounts of mRNA coding for three different growth factors and one receptor from the EGF system in a single RT-PCR reaction combined with calibration curves. In addition to offering practical advantages, the multiplex format of calibrated RT-PCR quantitation with an automated CE detection system is a fast, reproducible, and sensitive approach that can be applied to any biological system that requires analysis of several genes simultaneously in both clinical and experimental investigations.

\section{Acknowledgements}

The excellent technical assistance of Marianne Lysdahl is acknowledged.

\section{References}

Bor MV, Sørensen BS, Flyvbjerg A, Pedersen SB, Nexø E (2000). Epidermal growth factor and insulin- like growth factor I upregulate the expression of the epidermal growth factor system in rat liver. J Hepatol 32:645-654.

Bor MV, Sørensen BS, Rammer P, and Nexø E (1998). Calibrated user-friendly reverse transcriptase-PCR assay: Quantitation of epidermal growth factor receptor mRNA. Clin Chem 44:1154-1160.

Lu W, Han DS, Yuan J, and Andrieu JM (1994). Multi-target PCR analysis by capillary electrophoresis and laser-induced fluorescence. Nature 368:269-271.

Siebert PD and Larrick JW (1992). Competitive PCR. Nature 359:557-558.

Tsai SJ and Wiltbank MC (1996). Quantification of mRNA using competitive RT-PCR with standard-curve methodology. Bio Techniques 21:862-866.

Vats A, Katayama H, Km Y, Mauer M, Fish AJ, and McGlennen RC (1997). Modified method for competitive reverse transcription polymerase chain reaction for rapid and automated quantitation of messenger RNA in multiple samples. Mol Diagn 2:235-240. 